\title{
Morphogenetic Response of Cotyledon and Leaf Explants of Melon (Cucumis melo L.) cv. Amarillo Oro
}

\author{
Fernanda Vidigal Duarte Souza ${ }^{1 *}$, Begoña Garcia-Sogo ${ }^{2}$, Antonio da Silva Souza ${ }^{1}$, Amparo \\ Pérez San-Juán ${ }^{2}$ and Vicente Moreno ${ }^{2}$ \\ ${ }^{1}$ Laboratório de Biotecnologia Vegetal; Embrapa Mandioca e Fruticultura Tropical; C. P. 007; \\ 44380-000; Cruz das Almas - BA - Brasil. ${ }^{2}$ Laboratorio de Biotecnología de la Escuela Superior de \\ Inginieros Agrónomos de la Universidad Politecnica de Valencia - Valencia - España
}

\begin{abstract}
Callus cultures from cotyledon and leaf explants of a Spanish cultivar of melon (Amarillo Oro) were tested for growth and morphogenic capacity on several culture media with different concentrations of IAA (indole-3-acetic acid) in combination with $1.0 \mathrm{mg} . \mathrm{L}^{-1} \mathrm{BA}$ (6-benzylaminopurine) or $6.0 \mathrm{mg} . \mathrm{L}^{-1} \mathrm{KIN}$ (kinetin). The best results were achieved with cotyledon explants. The leaf explants presented low bud formation capacity. Variability of organogenic response on cotyledons of different age (7, 5, 3 and 1-day-old) was evaluated. The age of explant had a significant influence on bud induction. Cotyledon explants from 7-day-old seedlings showed higher organogenic index and development of shoots when cultured onto MS medium supplemented with $1.5 \mathrm{mg} . \mathrm{L}^{-1}$ of IAA and $1.0 \mathrm{mg} . \mathrm{L}^{-}$ ${ }^{1}$ of BA. The effect of cut type of cotyledonary explants on organogenic response was also investigated. Explants cut transversally showed the best results. The addition of copper sulfate in the culture medium promoted a qualitative improvement of the regenerated shoots.
\end{abstract}

Key words: Organogenesis, plant regeneration, leaf explant, cotyledon explant, cucurbitaceae

\section{INTRODUCTION}

The melon (Cucumis melo L.) which belongs to the Cucurbitaceae family has an important social and economic role, mainly in the tropical regions of both hemispheres. Biotechnology offers tools which are capable of surpassing some limitations found by traditional plant breeding methods, by developing new material, through genetic engineering, molecular biology and tissue culture techniques. However, for the use of these possibilities it is necessary to develop of in vitro plant regeneration protocols, allowing the recovery of improved material for further propagation.
In earlier studies on morphogenesis of melon, methods for plant regeneration from primary explants of cotyledons and leaves were established (Moreno et al., 1985; Ortz et al., 1987; GarcíaSogo, 1990; Bordas et al., 1991). Bordas (1994) carried out an additional study on the effect of type and concentration of gelling agents, besides confirming the effect of copper ion on the morphogenetic response in melon, as previously described by García-Sogo (1990). It has been demonstrated that morphogenetic response in melon is genotype dependent (Molina and Nuez, 1995; Souza, 1999). The establishment of a efficient plant regeneration protocol is also an essential step in the generation of new cultivars

\footnotetext{
* Author for correspondence
} 
through plant transgenic technology. Considering these information, the objective of this work was to establish protocol of plant regeneration of the melon cultivar Amarillo Oro suitable for studies on plant genetic transformation.

\section{MATERIAL AND METHODS}

\section{Plant Material}

Cotyledon and two different types of leaves were used as explant source, namely, L1 - the first leaf that emerged from in vitro cultivated seedling and L2 - leaves from in vitro micropropagated plants. Approximately $1 \mathrm{~cm}^{2}$ explants of all tissues were used in the experiments.

\section{Morphogenetic response of calli from cotyledon and leaf explants}

Three sequential experiments were carried out. The culture media used for organogenesis induction are described in Table 1. The variables studied in the three experiments were: 1) organogenic index: (mean \pm SE), measured by the mean value obtained from arbitrary values (from 0 to 3 ) for each explant according to the intensity of the organogenic response. The arbitrary value considers the extension of the areas with the buds as well as their development, whereas: $0=$ explant without bud formation; 1 = bud formation on less than half the explant extension; 2 = bud formation on approximately half the explant; $3=$ bud formation covering almost the full extention of the explant; and 2) the number of shoots per callus (mean $\pm \mathrm{SE}$ ).

In all experiments, the explants were incubated under $16 \mathrm{~h}$ photoperiod at $24 \pm 2{ }^{\circ} \mathrm{C}, 70 \%$ relative humidity and fluorescent light providing 30 $\mu \mathrm{E} \mathrm{m}^{-2} \mathrm{~s}^{-1}$.

Table 1 - Organogenesis induction media used in the experiments.

\begin{tabular}{|c|c|c|c|c|c|}
\hline & \multicolumn{5}{|c|}{ Organogenesis Induction Media } \\
\hline & IB $05 / 10$ & IB $075 / 10$ & IB $10 / 10$ & IB $15 / 10$ & $\begin{array}{c}\text { IK } \\
15 / 60 \\
\end{array}$ \\
\hline Basal Solution & $\mathrm{MS}^{*}$ & MS & MS & MS & MS \\
\hline Sucrose $\left(\mathrm{g} . \mathrm{L}^{-1}\right)$ & 30.0 & 30.0 & 30.0 & 30.0 & 30.0 \\
\hline Inositol ( $\left.\mathrm{g} \cdot \mathrm{L}^{-1}\right)$ & 0.1 & 0.1 & 0.1 & 0.1 & 0.1 \\
\hline $\begin{array}{l}\text { Thiamine-HCl } \\
\left({\left.\mathrm{mg} . \mathrm{L}^{-1}\right)}^{-}\right.\end{array}$ & 1.0 & 1.0 & 1.0 & 1.0 & 1.0 \\
\hline $\mathrm{IAA}\left(\mathrm{mg} \cdot \mathrm{L}^{-1}\right)$ & 0.5 & 0.75 & 1.0 & 1.5 & 1.5 \\
\hline BA $\left(m g . L^{-1}\right)$ & 1.0 & 1.0 & 1.0 & 1.0 & \\
\hline $\operatorname{KIN}\left(\mathrm{mg} \cdot \mathrm{L}^{-1}\right)$ & & & & & 6.0 \\
\hline $\mathrm{CuSO}_{4} 5 \mathrm{H}_{2} \mathrm{O}\left(\mathrm{mg} \cdot \mathrm{L}^{-1}\right)$ & 1.0 & 1.0 & 1.0 & 1.0 & 1.0 \\
\hline
\end{tabular}

"Murashigue and Skoog (1962).

\section{Experiment 1. Effect of explants source and the medium culture in growth and organogenic response \\ The experimental design was two-way factorial arrangement $3 \times 4$ on a CRD (three types of primary explants and four culture media) with 18 culture flasks with two explants per flask. repetition by treatment, each repetition represented by one explant. The explants used were leaves L1, leaves L2 and cotyledons from 7-day-old seedlings. The culture media IB 05/10; IB 075/10; IB 10/10; IB 15/10 were used. The experiment was evaluated after 30 days.}

Experiment 2. Effect of age, culture media and copper sulphate addition in the growth and morphogenetic response of cotyledon explants Four cotyledons ages - 1, 3, 5 and 7-day-old seedlings, two culture media (IB 15/10 and IK $15 / 60$ ) and two concentrations of copper sulphate $\left(0.025 \mathrm{mg} . \mathrm{L}^{-1}\right.$ - the standard concentration of MS and supplemented with $1.0 \mathrm{mg} \cdot \mathrm{L}^{-1}$ ) were investigated. The experimental design was threeway factorial arrangement $4 \times 2 \times 2$ on a CRD with 48 repetitions by treatment, each repetition represented by one explant. Two evaluations were carried out at 30 and 60 days of cultivation. 
Experiment 3. Effect of cut type, culture medium and copper sulphate on morphogenetic response of cotyledons explants

The experimental design was three way factorial arrangement $2 \times 2 \times 2$ on a CRD with 20 culture flasks with two explants per flask. Each repetition was represented by one explant. Cotyledons from 7-day-old-seedlings were used as explant and divided transversal and longitudinal into two equals parts, constituting two types of primary explants: transversal segments $(0.5 \mathrm{~cm} \times 0.5 \mathrm{~cm})$ and longitudinal segment $(1.0 \mathrm{~cm} \times 0.3 \mathrm{~cm})$. Two culture media (IK $15 / 60$ and IB 15/10) and the addition of copper sulphate were also investigated. The experiment was evaluated after 30 days.

\section{Statistical Analysis}

The transformation $\sqrt{x+5}$ was applied to the data of the variables organogenic index and number of buds per callus. The effects of treatments were tested by Analysis of Variance; differences among means were tested by LSD range test $(\mathrm{p}<0.05)$.

\section{RESULTS AND DISCUSSION}

\section{Effect of explant type and culture medium on growth and organogenic response}

The choice of an appropriated explant constitutes a main step in the establishment of plant regeneration protocols. Several protocols for melon have been described using different explants such as hypocotyls, cotyledons, leaves and roots (Moreno et al., 1985; Trulson and Shahin, 1986; Niedz et al., 1989; Bordas et al., 1991; Tabei et al., 1991; Souza, 1999; Souza, 2001; Lotfi et al., 2003). The results have shown that protocols using leaf explants were less efficient. However, studies with cucumber demonstrated that the frequency of polyploid cells was much lower in leaf explants, when compared with cotyledons and hypocotyl, which rise the interest for the working with more stable starting materials (Colijn-Hooymans et al., 1988). In cotyledon explants, callus formation on the cut surface was observed approximately at 15-20 days of cultivation, depending on the medium. The results of this study showed that the capacity of plant regeneration from leaf explant was much lower than cotyledons. Table 2 showed the effect of the interaction of explant with culture medium on the organogenic index, where cotyledons were superior in all studied culture media.

The most common regeneration protocols for melon use cotyledons as explant source, while the use of leaves is not frequent due to their lower morphogenetic response. One of the factors that contributed for this negative result was the occurrence of callus hyperhydricity. Yadav et al. (1996) reported different factors affecting melon regeneration from leaf explants including leaf age, the addition of silver nitrate to the medium and the type of gelling agent. Therefore, further studies on such subjects could offer an alternative for solving the problem.

Regarding the mean number of shoots per callus, cotyledons presented a good development of the formed buds into shoots. The buds from leaf explants, however, did not show the capacity to develop into shoots The best result was observed with cotyledons cultivated in IB $15 / 10$ medium (Table 3).

The evaluated culture media did not show significant difference on organogenic index. However, for the number of shoots per callus, higher auxin concentration, combined with 1.0 mg. $\mathrm{L}^{-1}$ of BA, favored the development of buds, resulting in a higher number of shoots (Table 3 ).

Table 2 - Effect of culture medium and explant source on organogenic index.

\begin{tabular}{lcccc}
\hline \multirow{2}{*}{ Explant } & \multicolumn{4}{c}{ Culture Media } \\
\cline { 2 - 5 } & IB 05/10 & IB 075/10 & IB 10/10 & IB 15/10 \\
\hline Cotyledon & $1.40 \pm 0.13^{\mathrm{aB}}$ & $1.60 \pm 0.14^{\mathrm{aAB}}$ & $1.90 \pm 0.12^{\mathrm{aA}}$ & $1.80 \pm 0.14^{\mathrm{aAB}}$ \\
Leaf L1 & $0.78 \pm 0.13^{\mathrm{bB}}$ & $1.10 \pm 0.15^{\mathrm{bB}}$ & $1.00 \pm 0.15 \mathrm{bB}$ & $1.40 \pm 0.12^{\mathrm{aA}}$ \\
Leaf L2 & $0.77 \pm 0.16^{\mathrm{bBC}}$ & $0.90 \pm 0.15^{\mathrm{bAB}}$ & $1.10 \pm 0.17^{\mathrm{bA}}$ & $0.47 \pm 0.11^{\mathrm{bC}}$ \\
\hline
\end{tabular}

The numbers indicate mean \pm SE. Values followed by different lower case letter within the column are significantly different at $5 \%$ level. Values followed by different upper case letter within the row are significantly different at $5 \%$ level. 
Table 3 - Effect of culture medium and explant source on number of shoots per callus.

\begin{tabular}{lcccc}
\hline \multirow{2}{*}{ Explant } & \multicolumn{4}{c}{ Culture Media } \\
\cline { 2 - 5 } & IB 05/10 & IB 075/10 & IB 10/10 & IB 15/10 \\
\hline Cotyledon & $0.80 \pm 0.14^{\mathrm{aB}}$ & $1.10 \pm 0.15^{\mathrm{aB}}$ & $1.30 \pm 0.15^{\mathrm{aA}}$ & $1.50 \pm 0.14^{\mathrm{aA}}$ \\
Leaf L1 & $0.20 \pm 0.09^{\mathrm{bA}}$ & $0.08 \pm 0.09^{\mathrm{cA}}$ & $0.05 \pm 0.07^{\mathrm{bA}}$ & $0.04 \pm 0.06^{\mathrm{bA}}$ \\
Leaf L2 & $0.14 \pm 0.11^{\mathrm{bB}}$ & $0.60 \pm 0.12^{\mathrm{bA}}$ & $0.22 \pm 0.11^{\mathrm{bAB}}$ & $0.08 \pm 0.07^{\mathrm{bB}}$ \\
\hline
\end{tabular}

The numbers indicate mean \pm SE. Values followed by different lower case letter within the column are significantly different at 5\% level. Values followed by different upper case letter within the row are significantly different at $5 \%$ level.

Effect of age, culture medium and addition of copper sulfate on growth and organogenic response in cotyledon explants

According to the Analysis of Variance, the age of cotyledons was highly significant for both studied variables. The highest organogenic index and number of shoots per callus were observed in seven-day-old cotyledons after 30 and 60 days of cultivation (Figs. 1 and 2).

Moreno et al. (1985) tested several culture media with different concentrations of IAA and KIN in Amarillo Oro cultivar. The most effective combination for organogenic response was 1.5 mg. $\mathrm{L}^{-1}$ of IAA and $6.0 \mathrm{mg} . \mathrm{L}^{-1}$ of KIN (IK 15/60). Since then, such medium has been the most commonly used in melon regeneration studies with different melon cultivars (Bordas, 1994). However, preliminary experiments conducted in our laboratory has shown that IB 15/10 medium was more efficient than IK $15 / 60$ in plant regeneration of some melon cultivars (data not shown). Therefore, this experiment was also carried out to investigate the effect of IB 15/10 medium in the cultivar Amarillo Oro. The analysis of number of shoots per callus, at 30 days of cultivation confirmed that IB $15 / 10$ was more efficient than IK 15/60 (Fig. 4).

Organogenic response in Cucurbitaceae is highly genotype dependent. Ficcadenti and Rotini (1995) reported shoot production in 11 melon cultivars using BA as growth regulator. In addition, Dabaúza (1995) obtained an expressive organogenic response in cotyledon explants from Citrullus colocynthis, using only BA as growth regulator. Recently, Souza (1999) reported the organogenic response of explants from several cultivars in two culture media, where in one of them only $1.0 \mathrm{mg} . \mathrm{L}^{-1}$ of BA was added, while in the other IAA and KIN were supplemented. The number of shoots per callus was higher in the cultivars Shipper and Melón de Onteniente when BA was used in the culture medium, while for the cultivars Eldorado 300, Amarelo and Cantaloup Charentais, IK 15/60 medium was more efficient.

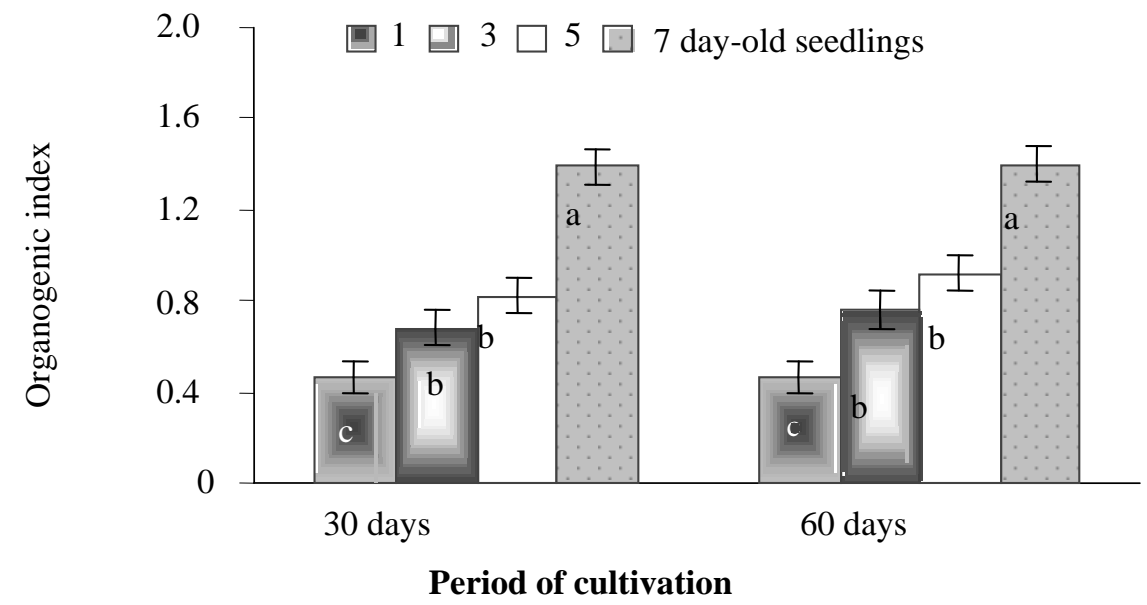

Figure 1 - Effect of cotyledon age on organogenic index at 30 and 60 days of culture the two culture media. Columns with different letter in the same period of cultivation are statistically different at $5 \%$ level; the bars represent the stand error. 


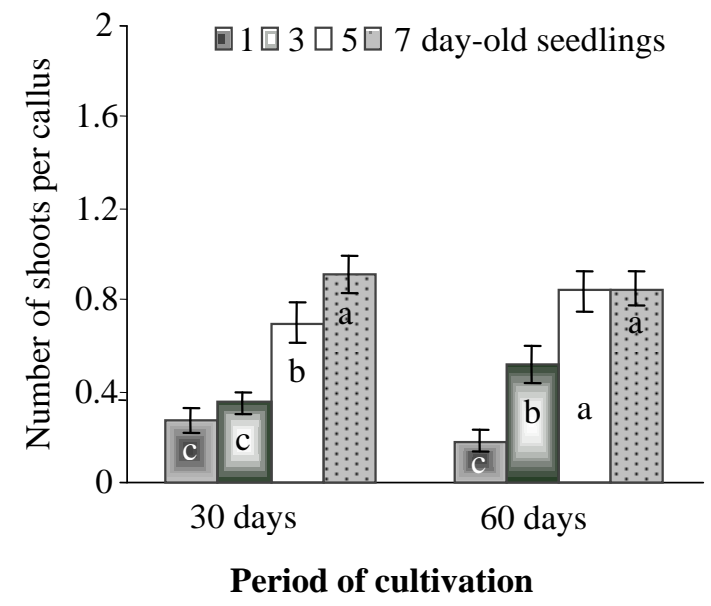

Figure 2 - Effect of cotyledon physiological stage on number of shoots per callus at 30 and 60 days of culture in the two culture media. Columns with different letter in the same period of cultivation are statistically different at $5 \%$ level; the bars represent the stand error.

Although significant improvement by the addition of copper sulfate on culture media was observed in many melon cultivars (García-Sogo, 1990; Bordas, 1994; Souza, 1999), in our experiment, there was no significant change on the organogenic index and number of shoots per callus. Our results indicated that the age of cotyledon had a great influence on organogenic response. Therefore, further experiments were conducted using 7-dayold cotyledon explants.
Effect of cut type, culture medium and copper sulfate addition on growth and organogenic response in primary cotyledons explants

Even though the isolated effect of cut type was not significant, the interaction between with the culture medium was significant for both organogenic index and number of shoots per callus. The highest values were registered when cotyledons were cut transversally and cultivated in IB 15/10 medium (Fig. 4).

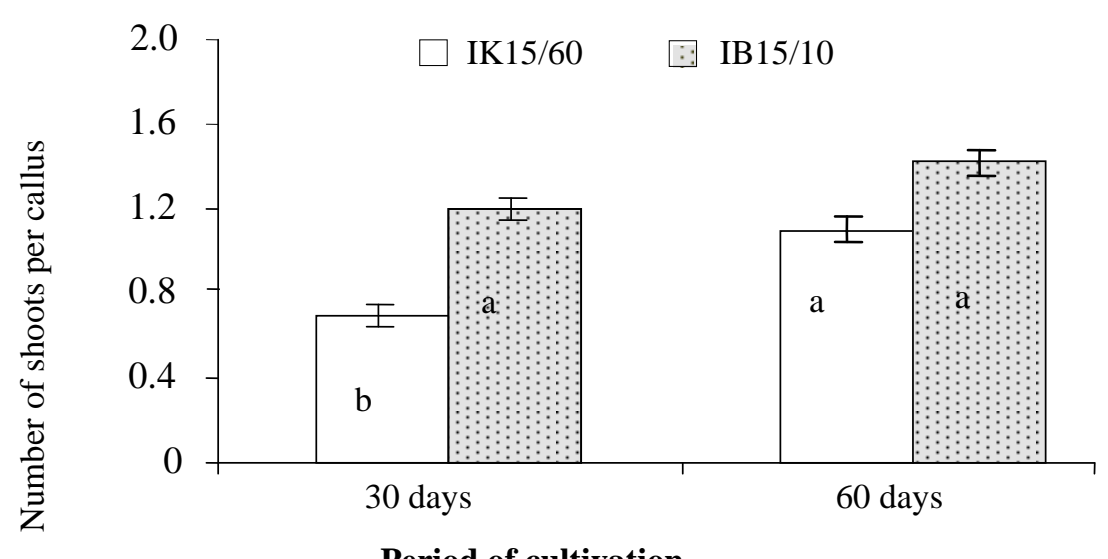

Figure 3 - Effect of culture medium on number of shoots per callus at 30 and 60 days of culture. Columns with different letter in the same period of cultivation are statistically different at $5 \%$ level; bars represent the stand error. 


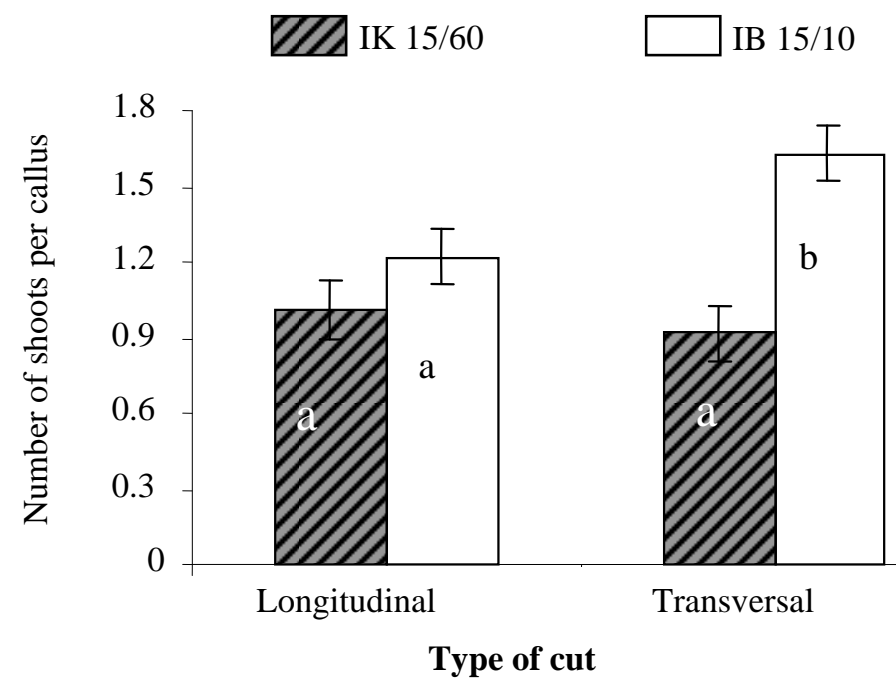

Figure 4 - The effect of cut and culture medium on numbers of shoots per callus. Columns with different letter in the same type of cut are statistically different at 5\% level; the bars represent the stand error.

The culture medium IB $15 / 10$ promoted a significant increase on both organogenic index and number of shoots per callus. As the concentration of IAA was the same in both culture media, it suggested that, for this cultivar, $1.0 \mathrm{mg} . \mathrm{L}^{-1}$ of $\mathrm{BA}$ was more effective than $6.0 \mathrm{mg} . \mathrm{L}^{-1}$ of $\mathrm{KIN}$ on organogenic induction.

There are few reports on morphogenesis in cucurbits that describe the effect of cut type of explants. In cucumber, Gambley and Dodd (1991) evaluated many cut types on cotyledons and found that when the basal region was not present in the explant, there was no shoot production, independently of the culture medium used. In this work, although the results of copper sulfate addition in the culture medium were not quantitatively significant, it promotes a qualitative improvement of the regenerated plants (data not shown).The plant regeneration protocol established in this work was suitable and currently in use at our laboratory for plant genetic transformation studies.

\section{ACKNOWLEDGEMENTS}

We thank to the CAPES for the scholarship during this work.

\section{RESUMO}

Explantes de cotilédones e folhas do cultivar de melão Amarillo Oro foram cultivados para avaliação do potencial morfogenético em diferentes meios de cultura com diversas concentrações de ácido indolacético (AIA), em combinação com 1,0 mg. $\mathrm{L}^{-1}$ benziladenina (BA) e 6,0 mg. $\mathrm{L}^{-1}$ de cinetina (CIN). Os melhores resultados foram obtidos com explantes de cotilédones, sendo que explantes de folhas mostraram uma capacidade baixa na indução de gemas. A variação na resposta organogênica em cotilédones de diferentes idades fisiológicas $(1,3$, 5 e 7 dias após a germinação) mostraram que os melhores resultados foram obtidos com cotilédones de sete dias cultivados no meio MS suplementado com 1,5 mg. $\mathrm{L}^{-1}$ de AIA e 1,0 mg.. $\mathrm{L}^{-1}$ de BA. O efeito do tipo de corte na resposta organogênica de explantes cotiledonares foi também avaliado. Os melhores resultados foram obtidos com explantes cortados transversalmente. Adição suplementar de sulfato de cobre ao meio de cultura resultou em uma melhora na qualidade da dos brotos regenerados. 


\section{REFERENCES}

Bordas, M.; Moreno, V. and Roig, L. (1991), Organogenic and embryogenic potential of several commercial lines of Cucumis melo. Cucurbit Genetics Cooperative, 14, 71-74.

Bordas, M. (1994), Ingeniería Genética en Melón (Cucumis melo L.): Transferencia, Integración y Expresión de Genes Foráneos. 483 ff. Tesis (Doctorado en Ingeniería Agronómica) - E.T.S.I.A. Universidad Politécnica de Valencia, España.

Colijn-Hooymans, C. M.; Bouwer, R.; Orczy, W. and Dons, J. J. M. (1988), Plant regeneration from cucumber (Cucumis sativus) protoplasts. Plant Sci., 57, 63-71.

Dabaúza, M. (1995), Selección y caracterización de híbridos somáticos Cucumis melo L. (+) Cucumis anguria L. var. longipes, Cucumis melo L. (+) Cucumis myriocarpus Naud y Cucumis melo L. (+) Citrullus colocynthis (L) Schard. 272 ff. Tesis (Doctorado en Ciencias Biológicas), E.T.S.I.A. Universidad Politécnica de Valencia, España.

Ficcadenti, N. and Rotino, G. L. (1995), Genotype and medium affect shoot regeneration of melon. Plant Cell, Tissue and Organ Culture, 40 : (3), 293-295.

Gambley, R. L. and Dodd, W. A. (1991), The influence of cotyledons in axillary and adventious shoot production from cotyledonary nodes of Cucumis sativus L. (cucumber). Journal of Experimental Botany, 42 : (242), 1131-1135.

García-Sogo, B. (1990), Morfogénesis en cultivo in vitro de melón: regeneración de plantas con alta eficácia a partir de células y protoplastos. $337 \mathrm{ff}$. Tesis (Doctorado en Ciencias Biológicas) Facultad de Ciencias Biológicas, Universidad de Valencia, España.

Lotfi, M.; Alan, A. R.; Henning, M. J.; Jahn, M. M. and Earle, E. D. (2003), Production of haploid and doubled haploids plants of melon (Cucumis melo L.) for use in breeding for multiple virus resistance. Plant Cell Reports, 21, 1121-1128.

Molina, R. V. and Nuez, F. (1995), Correlated response of in vitro regeneration capacity from different source of explants in Cucumis melo. Plant Cell Reports, 15 : (1/2), 129-132.

Moreno, V.; García-Sogo, M.; Granell, I.; García-Sogo, B. and Roig, L. A. (1985), Plant regeneration from calli of melon (Cucumis melo L. cv. Amarillo Oro). Plant Cell, Tissue and Organ Culture, 5 : (2), 139146.

Niedz, R. P.; Smith, S. S.; Dunbar, K. B.; Stephens, C. T. and Murakishi, H. H. (1989), Factors influencing shoot regeneration from cotyledonary explants of Cucumis melo. Plant Cell, Tissue and Organ Culture, 18, 313-319.
Ortz, M. C.; Garcia-Sogo, B.; Roche, M.; Roig, L. A. and Moreno, V. (1987), Morphogenetic response of calli derived from primary explants of diverse cultivars of melon. HortScience, 22 : (4), 666.

Souza, A. S. (1999), Respuesta cultural y morfogenética de explantes y protoplastos de diversos cultivares de melón y primeros resultados en torno a la hibridación somática Cucumis melo L. (+) Citrullus lanatus (Thumberg) Matsumura and Nakay. 190 ff. Tesis (Doctorado en Ingeniería Agronómica) E.T.S.I.A, Universidad Politécnica de Valencia, España.

Souza, F. V. D. (2001), Transformación genética en melón (Cucumis melo L.) y tomate (Lycopersicon esculentum) com los genes chit 42 y bgn 16.2 para la obtención de plantas resistentes a enfermedades fúngicas. 179 ff. Tesis (Doctorado en Biología Celular) E.T.S.I.A. Universidad Politécnica de Valencia, España.

Tabei, Y.; Kitade, S.; Nishizawa,Y. and Kikuchi, N. (1991), Transgenic cucumber plants harboring a rice chitinase gene exhibit enhanced resistence to gray mold (Botrytis cinerea). Plant Cell Reports, 17, 159164.

Trulson, A. J. and Shahin, E. A. (1986), In vitro plant regeneration in the genus Cucumis. Plant Science, $\mathbf{4 7}$ : (1), 35-43.

Yadav, R. C.; Saleh, M. T. and Grumet, R. (1996), High frequency shoot regeneration from leaf explants of muskmelon. Plant Cell, Tissue and Organ Culture, 45 : (3), 207-214.
Received: May 04, 2004; Revised: February 22, 2005; Accepted: July 28, 2005. 